\title{
EFFECTS OF GLYPHOSATE ON ENZYME ACTIVITY AND SERUM GLUCOSE IN RATS Rattus norvegicus
}

\author{
HASKOVIĆ Edhem ${ }^{1}$, PEKIĆ Melina ${ }^{1}$, FOČAK Muhamed ${ }^{1 *}$, SULJEVIĆ Damir ${ }^{1}$, \\ MEŠALIĆ Lejla ${ }^{2}$
}

${ }^{1}$ Department of Biology, Faculty of Science, Zmaja od Bosne 33-35, Sarajevo, Bosnia and Herzegovina

${ }^{2}$ Public Health Center „Mustafa Šehovic““, Albina Herljevića 1, Tuzla, Bosnia and Herzegovina

(Received 24 June 2015; Accepted 24 February 2016)

Glyphosate is a pesticide that influences many blood parameters if taken orally or subcutaneously. This pesticide causes important changes in the metabolic activity which can be measured by organospecific enzyme activity such as liver aminotransferases (AST and ALT), while glucose acts as a stress, energy and metabolism indicator after acute glyphosate exposure. In this research, glyphosate was applied subcutaneously to rats, administrated each 24 hours for a 15 days period. The concentration of the applied glyphosate was $2.8 \mathrm{~g} / \mathrm{kg}$. The experimental rats were 13 weeks old. The concentration of serum glucose, the activity of lactate dehydrogenase and liver transaminases (AST and ALT) were observed as indicators of metabolic changes after treatment. It was observed that glyphosate led to a statistically significant decrease of serum glucose level. Statistically significantly increased $(\mathrm{p}<0.05)$ AST, ALT and LDH activities are indicators of hepatocyte damage while $\mathrm{LDH}$ activity demonstrates damage of other tissues.

Key words: ALT, AST, serum glucose, glyphosate, LDH, Wistar strain rat

\section{INTRODUCTION}

Glyphosate is a reactive biological molecule used during the last 30 years as broadspectrum synthetic pesticide. In comparision to other pesticides it shows a lower mobility and lower level of toxicity for animals. For a period of time, glyphosate was used as the least harmful pesticide, until recent studies which showed that glyphosate can bring some risks when used. It was concluded that glyphosate causes damage of human cells even in small doses [1,2]. Some studies name glypohosate as the main factor for cancer occurrence and non-Hodgkin lymphoma [3]. Experiments done on rats showed that it does not cause skin cancer directly, but it enhances its development [4]. These investigations corroborated examinations that had been done previously

*Corresponding author: e-mail: mfocak10@mail.com 
[5]. The experiments were designed in a way that rats were fed a feed containing radioactively marked glyphosate and it was noticed that this substance is absorbed by the organism to a level of $15 \%$ to $36 \%$, while the remaining is eliminated by the digestive tract. Absorbed glyphosate is eliminated unmetabolized from the organism [6]. It is not absorbed by the skin, respiratory or digestive tract, and the median lethal dose for rats is higher than $4320 \mathrm{mg} / \mathrm{kg}$ [7]. Studies of the effects of organophosphate pesticides, namely Diazonine, were done on rats. They were divided into two groups. One group was treated with vitamins A, C and E plus Diazinon, and the other group was treated with this pesticide, only. After the treatment, the concentrations of hepatic aminotransferases were extremely high in the second group compared to the first group which shows that vitamins $\mathrm{A}, \mathrm{C}$ and $\mathrm{E}$ have a potent antioxidative and protective effect on the liver [8]. Glyphosate can cause some serious poisoning if inhaled, even at low concentrations $[9,10]$. In one study a significant relationship between glyphosate and skin cancer was observed [11]. Another study showed that glyphosate can act as an endocrine disruptor (xenochormone) and can interfere with the endocrine system in animals and humans. It interferes with normal estrogen production and causes hormone-depended breast cancer [12]. Two other properties of glyphosate have also a negative impact on health, i.e. chelation of minerals such as iron and cobalt and interference with cytochrome P450 (CYP) enzymes, which have a number of important roles in the body. Thus, while short-term studies in rodents have shown no apparent toxicity [13], studies involving life-long exposure in rodents have demonstrated liver and kidney dysfunction and a greatly increased risk of cancer, with a shortened lifespan [14]. The aim of this study was to evaluate the actions of herbicide glyphosate on rats' health status due to the fact that glyphosate is being used intensively in agriculture in the last years.

\section{MATERIAL AND METHODS}

Rattus norvegicus (Wistar strain) lab rats, bred at the Physiological laboratory, Department of Biology, University of Sarajevo, Bosnia and Herzegovina were used for this research. The activities of aspartate aminotransferase (AST), alanine aminotransferase (ALT), lactate dehydrogenase $(\mathrm{LDH})$ and the concentration of glucose were measured. The analyses were done both in the control (30) and experimental (30) groups of animals. Both groups were about the same age ( 13 weeks). The performed experiments comply with the current legislation, and animals were treated in accordance to the Ethics Review committee of the Faculty of Science, University of Sarajevo. Appropriate care, accommodation and manipulation of the animals during the experiment, thus preventing the abuse of animals and safe work were included. Rats were fed with Oxbow Essentials pellets for rats which is a low-fat and nutritionally-balanced food.

Experimental design. Before the experiment, body mass was determined in order to accurately apply the doses of glyphosate. Animals were anaesthetized with sufentanil/ medetominide $(50 / 150 \mu \mathrm{g} / \mathrm{kg})$ before cardiopunction by subcutaneous application. 
Administration of glyphosate (Total 480 SL, Genera, Croatia) was done by applying subcutaneously a small amount every day at the same time for 15 days. Proper dosage of glyphosate to achieve the wanted effect in rats was calculated by Clarc's formula. Collected blood samples were transferred to test tubes without anticoagulants for serum analysis. The next step was centrifugation (Heraeus-Sepatech, Germany)at 3000 rpm for 15 minutes.

The values of AST, ALT, LDH and glucose were obtained at the Veterinary Faculty in Sarajevo by an autoanalyzer (Vet'Test 8008, USA). The results of the collected data were elaborated with methods of descriptive and analytical statistics (Student's t-test, ANOVA and Kolmogorov-Smirnov test) by using Microsoft Excel 2010, Biostat 2009 and SPSS Statistics 17.0.

\section{RESULTS}

After laboratory analysis the obtained results were statistically processed. Results of serum biochemical analysis of control and experimental groups of rats are shown in table 1 (Table 1).

Table 1. Values of biochemical parameteres in the control $(n=30)$ and experimental group $(\mathrm{n}=30)$

\begin{tabular}{lcccccccc}
\hline & \multicolumn{2}{c}{ Glucose $(\mathbf{m m o l} / \mathbf{l})$} & \multicolumn{2}{c}{ ALT (U/1) } & \multicolumn{2}{c}{ AST (U/1) } & \multicolumn{2}{c}{ LDH (U/1) } \\
\cline { 2 - 10 } & Cont. & Exp. & Cont. & Exp. & Cont. & Exp. & Cont. & Exp. \\
\hline Average value & 5.61 & 1.94 & 123.20 & 182.81 & 179.31 & 362.91 & 275.70 & 579.02 \\
Standard deviation & 0.60 & 0.87 & 12.80 & 10.45 & 11.20 & 17.67 & 16.25 & 33.74 \\
Maximum value & 6.58 & 3.20 & 152.00 & 196.38 & 195.60 & 385.20 & 293.00 & 620.50 \\
Minimum value & 4.90 & 0.89 & 109.00 & 169.38 & 159.60 & 325.60 & 245.00 & 532.40 \\
Coefficient of variation & 10.68 & 44.70 & 10.39 & 5.71 & 6.24 & 4.87 & 5.89 & 5.83 \\
\hline
\end{tabular}

The average values of AST, ALT and LDH in the control group were $123.20 \mathrm{U} / 1$, $179.31 \mathrm{U} / 1$ and $275.70 \mathrm{U} / 1$, respectively. The average concentration of glucose in the control group was $5.61 \mathrm{mmol} / \mathrm{l}$. The biggest coefficient of variation was recorded in the values for glucose.

Average values of AST, ALT and LDH in the experimental group were $182.81 \mathrm{U} / \mathrm{l}$, $362.91 \mathrm{U} / 1$ and $579.02 \mathrm{U} / \mathrm{l}$, respectively. The average glucose concentration was $1.94 \mathrm{mmol} / \mathrm{l}$. The highest coefficient of variation was noted in glucose concentration due to a wide range of individual variations. Statistical evaluation is presented in table 2 (Table 2). Student's t-test, ANOVA and Kolmogorov-Smirnov tests were done to evaluate the statistical significance of the collected data.

Statistical analysis (t-test, ANOVA and Kolmogorov-Smirnov test) showed uniform results. There is statistical significance between the compared biochemical parameters 
(AST, ALT, LDH and glucose) between the control and experimental group on the level of $\mathrm{p}<0.00$. Kolmogorov-Smirnov test shows the presence of a normal distribution of the analyzed parameters for individual cases. The comparative average values of glucose, enzyme activity of AST, ALT and LDH is presented in figure 1 (Figure 1).

Table 2. Statistical evaluation of the control and experimental group

\begin{tabular}{lccccc}
\hline & & Glucose & ALT & AST & LDH \\
\hline \multirow{2}{*}{ Average } & Control & 5.61 & 123.20 & 179.31 & 275.70 \\
& Experimental & 1.94 & 182.81 & 362.91 & 579.02 \\
Student's t- test & $\mathrm{p}$ & 0.00. & 0.00. & 0.00. & 0.00. \\
\multirow{2}{*}{ ANOVA } & Sig. & $\mathrm{p}<0.05$ & $\mathrm{p}<0.05$ & $\mathrm{p}<0.05$ & $\mathrm{p}<0.05$ \\
& $\mathrm{p}$ & 0.00. & 0.00. & 0.00. & 0.00. \\
\multirow{2}{*}{ Kolmogorov-Smirnov test } & Sig. & $\mathrm{p}<0.05$ & $\mathrm{p}<0.05$ & $\mathrm{p}<0.05$ & $\mathrm{p}<0.05$ \\
& $\mathrm{p}$ & 0.946 & 0.877 & 1.279 & 1.499 \\
\hline
\end{tabular}

*Normal distribution

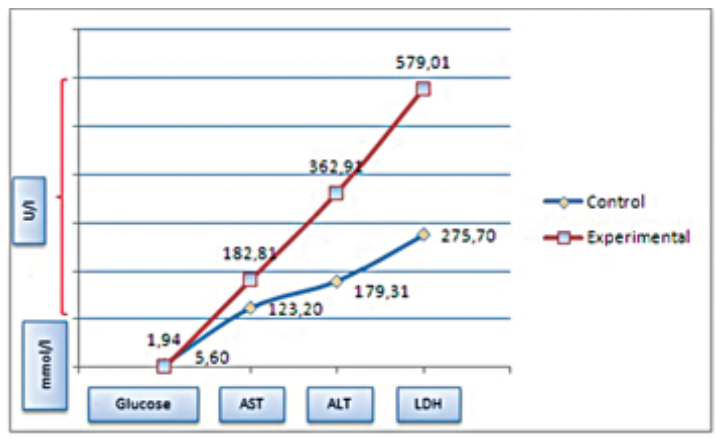

Figure 1. Values of glucose and enzyme activity in both control and experimental groups.

\section{DISCUSSION}

The effects of glyphosate on blood biochemical parameters were obvious. Measured values of AST in the control group were higher than those in the reference range. The reference range for AST in rats is 39-111 U/l. After statistical evaluation, values of AST were higher when comparing experimental and control groups of rats. Subcutaneous application of glyphosate led to the emergence of necrotic lesions in the liver, membrane damage of hepatocytes and increases of AST in the blood serum. The same results were reported by a number of authors [15]. The average range of ALT was slightly increased in both control and experimental groups. The reference range of AST in rats varies between 20 and $61 \mathrm{U} / 1$. The results in the experimental group showed ALT values as due to possible necrotic lesions in the liver. In one study 
it has been investigated that $1 \%$ glyphosate oral exposure affects the lipid peroxidation and antioxidant enzyme systems in the maternal serum and liver of pregnant rats and their term fetuses at 21 days of gestation. The results suggest that excessive lipid peroxidation induced with glyphosate ingestion leads to an overload of maternal and fetal antioxidant defense systems [16]. Elevated levels of liver enzymes in general signify some form of liver damage or injury. These levels may be elevated acutely (short term) indicating sudden injury to the liver. Glucose concentration in control rats was within the reference range $(50-135 \mathrm{mg} / \mathrm{dl})$. After the application of glyphosate it was concluded that the level of glucose was decreased in most cases. The main reason is that pesticides act as a stress factor which causes hypoglycemia. It is important to be aware that repeated episodes of stress can cause serious changes in blood sugar levels and increase the risk of hypoglycemia. Constant stress will also cause adrenal fatigue leading to adrenal failure. The values of LDH were very high in both control and experimental groups of rats. After the administration of glyphosate the LDH activity rises. LDH is an enzyme that is found in almost all of the body's cells and is released from cells into the fluid portion of blood when cells are damaged or destroyed. It is a general indicator of the existence and severity of acute or chronic tissue damage. Because LDH is found in many tissues throughout the body, complete LDH levels alone will not be enough to determine the location and cause of tissue damage. In liver disease, elevations of LDH are not as great as the increase in aspartate aminotransferase (AST) and alanine aminotransferase (ALT). With glyphosate, increased activity of extracellular lactate dehydrogenase is indicative for membrane damage and it was observed at doses $>80 \mathrm{mg} / 1$ [17] which is consistent to our research. In the present study structural damage could be correlated with the significant increase $(p<0.05)$ in aspartate aminotransferase, alanine aminotransferase, and alkaline phosphatase activities in the second and third month of exposure. The results indicate that longterm exposure to glyphosate at sublethal concentrations has adverse effects on the histopathological and biochemical alterations [18]. The results from another research suggest that maternal exposure to glyphosate during pregnancy induces a variety of functional abnormalities in the specific activity of the enzymes in the studied organs of pregnant rats and their fetuses [19]. Significant increases in the levels of hepatic enzymes (ALT, AST, and GGT) were observed after glyphosate herbicide treatment in one study [20] which is comparable with our research. The P-450 enzyme system is one of the main body systems for detoxifying many harmful chemicals. Glyphosate decreased the hepatic function of cytochrome P-450, monoxygenase activity and the intestinal activity of aryl hydrocarbon hydrolase [21].

\section{CONCLUSIONS}

Based on the obtained data, it is possible to perform the following conclusions: Subcutaneous injection of glyphosate affected the activity of enzymes AST, ALT, LDH and plasma glucose. Subcutaneous application of glyphosate resulted in an enormous 
increase of AST activity in the serum of rats. The value of glucose in experimental rats was reduced. Injection of glyphosate led to a statistically significant increase in enzyme activity of AST, ALT and LDH in the blood serum of rats. Application of glyphosate led to a statistically significant decrease in the concentration of glucose. Enzyme activity did not show significant differences between males and females of the control and experimental group. There is a great need for further researches of LDH izoenzymes (LDH-1 to LDH-5) by electrophoresis. These analyses should be conducted to see which tissue would be damaged the most by the toxic effects of glyphosate.

\section{List of abbreviations}

AST-aspartate aminotransferase

ALT-alanine aminotransferase

LDH-lactat dehydrogenase

ANOVA-analysis of variance

GGT-gamma glutamyltransferase

Cont-control group

Exp-Experimental group

\section{Authors' contributions}

HE gave his contribution in explaining physiological and biochemical mechanisms of analysed samples and also worked on Discussion and Material and Method sections. PE collected samples in laboratory and compared results with recent literature and worked on Discussion section. FM has done statistical analysis, collected references and done Intruduction and Results sections. SD worked in laboratory, analysed collected samples, collected references and has done Material and Methods section. ML collected samples and helped creating experimental design and analysing them.

\section{Declaration of conflicting interests}

The author(s) declared no potential conflicts of interest with respect to the research, authorship, and/or publication of this article.

\section{LITERATURE}

1. Benachour N, Séralini GE: Glyphosate formulations induce apoptosis and necrosis in human umbilical, embryonic, and placental cells. Chem Res Toxicol 2009; 22(1):97-105.

2. Gasnier C, Dumont C, Benachour N, Clair E, Chagnon MC, Séralini GE: Glyphosate-based herbicides are toxic and endocrine disruptors in human cell line. Toxicol 2009; 262(3):184191. 
3. Eriksson M, Hardell L, Carlberg M, Åkerman M: Pesticide exposure as risk factor for non-Hodgkin lymphoma including histopathological subgroup analysis. Int J Canc 2008; 123:1657-1663.

4. Daruich D, Zirulnik F, Gimenez MS: Effect of the Herbicide Glyphosate on Enzymatic Activity in Pregnant Rats and Their Fetuses. Env Res 2001; 85(3):226-231.

5. Marc J, Mulner-Lorillon O, Bellé R: Glyphosate-based pesticides affect cell cycle regulation. In: Biology of the Cell. Weinheim, Germany: Wiley-VCH Verlag; 2004,31-95

6. Williams GM, Kroes R, Munro IC: Safety evaluation and risk assessment of the herbicide roundup and its active ingredient glyphosate for humans. Reg Toxicol Pharm 2000; 31:17165.

7. Cox C: Glyphosate, Part 1: Toxycology. J Pestic Reform 1995; 15(3):14-20.

8. Shokrzadeh M, Shobi S, Attar H, Shayegan S, Payam SS, Ghorbani F: Effect of vitamins $\mathrm{A}, \mathrm{E}$ and $\mathrm{C}$ on liver enzyme activity in rats exposed to organophosphate pesticide diazinon. Pak J Bio Sci 2012;15(19):936-41.

9. Martinez TT, Long WC, Hiller R: Comparison of the toxicology of the herbicide roundup by oral and pulmonary routes of exposure. Proc W Pharm Soc 1990; 193-197.

10. Tai T, Yamashita M, Wakimori H: Hemodynamic effects of Roundup, Glyphosate and Surfactant in dogs. Jap J Toxicol 1990; 5:63-68.

11. George J, Prasad S, Mahmood Z, Shukla Y: Studies on glyphosate-induced carcinogenicity in mouse skin. J Prot 2010; 73(5):951-964.

12. Thongprakaisanga S, Thiantanawatb A, Rangkadiloka N, Suriyoc T, Satayavivad J: Glyphosate induces human breast cancer cells growth via estrogen receptors. Food and Chem Toxicol 2013; 59:129-136.

13. Smith EA, Oehme FW: The biological activity of glyphosate to plants and animals: A literature review. Vet Hum Toxicol 1992; 34, 531-543.

14. Séralini GE, Clair E, Mesnage R, Gress S, Defarge N, Malatesta MD: Spiroux de Vend'omois, J. Long term toxicity of a Roundup herbicide and a Roundup-tolerant genetically modified maize. Food Chem Toxicol 2012; 50:4221-4231.

15. Bradberry SM, Proudfoot AT, Vale JA. Glyphosate poisoning. Toxicol Rev 2004; 23(3):15967.

16. Beuret CJ, Zirulnik F, Giménez MS: Effect of the herbicide glyphosate on liver lipoperoxidation in pregnant rats and their fetuses. Reprod Toxicol 2005; 19(4):501-4.

17. Koller VJ, Fürhacker M, Nersesyan A, Mišík M, Eisenbauer M, Knasmueller S: Cytotoxic and DNA-damaging properties of glyphosate and Roundup in human-derived buccal epithelial cells. Arch Toxicol 2012; 86(5):805-813

18. Jiraungkoorskul W, Upatham ES, Kruatrachue M, Sahaphong S, Vichasri-Grams S, Pokethitiyook P: Biochemical and histopathological effects of glyphosate herbicide on Nile tilapia (Oreochromis niloticus). Environ Toxicol 2003; 18:260-267.

19. Williams AL, Watson RE, DeSesso JM: Developmental and reproductive outcomes in humans and animals after glyphosate exposure: a critical analysis. J Toxicol Environ Health 2012, 15;39-96.

20. Jasper R, Locatelli GO, Pilati C, Locatelli C: Evaluation of biochemical, hematological and oxidative parameters in mice exposed to the herbicide glyphosate-Roundup ${ }^{\circledR}$ Interdiscip Toxicol 2012; 5(3):133-140. 
21. Heitanen E, Linnainmaa K, Vainio H: Effects of phenoxyherbicides and glyphosate on the hepatic and intestinal biotransformation activities in the rat. A Pharmacol Toxicol 1983; 53(2):103-12.

\title{
EFEKTI GLIFOSATA NA ENZIMSKU AKTIVNOST I GLUKOZU U SERUMU KOD PACOVA Rattus norvegicus
}

\author{
HASKOVIĆ Edhem, PEKIĆ Melina, FOČAK Muhamed, SULJEVIĆ Damir, \\ MEŠALIĆ Lejla
}

Glifosat je pesticid koji utiče na mnoge parametre u krvi ukoliko se unese oralno ili subkutano. Ovaj pesticid izaziva snažne promene u metaboličkoj aktivnosti što se može meriti promenama aktivnosti organospecifičnih enzima, među kojima su najznačajniji aminotransferaze (AST i ALT), dok je glukoza indikator stresnog stanja i energetskog metabolizma nakon akutnog tretmana glifosatom. U ovom istraživanju, glifosat je apliciran subkutano, na svakih 24 časa u periodu od 15 dana. Doza glifosata korišćena u ovom tretmanu iznosila je $2.8 \mathrm{~g} / \mathrm{kg}$. Eksperimentalni pacovi su bili starosne dobi od 13 nedelja. Koncentracija serumske glukoze, aktivnost laktat dehidrogenaze i jetrenih transaminaza (AST i ALT) su analizirane kao indikatori promena koje su nastupile nakon tretmana glifosatom. Utvrđeno je da glifosat dovodi do statistički značajnog sniženja koncentracije serumske glukoze. Povećanje aktivnosti AST, ALT i LDH $(p<0.05)$ u serumu je indikator oštećenja hepatocita i njihovog isplavljivanja dok promene LDH ukazuje na oštećenja drugih tkiva i organa. 